\title{
MOTIVATIONAL FACTORS FOR DEDICATION AT WORK - CASE STUDY
}

UDC 331.103.3(497.11)

\author{
Dragan Dinić ${ }^{1}$, Vesna Miltojević ${ }^{2}$ \\ ${ }^{1}$ Marbo Product, Novi Sad, Serbia \\ ${ }^{2}$ University of Niš, Faculty of Occupational Safety, Niš, Serbia
}

\begin{abstract}
Motivation for work in altered social circumstances in the Republic of Serbia has rarely been the topic of research. Also, literature review suggests that it had not been a topic of interest before the break-up of the Socialist Federal Republic of Yugoslavia (SFRY) and the transition processes in Serbia. After a brief overview of different approaches to motivation and motivation for work and a presentation of the results of the research conducted in the former SFRY and the Republic of Serbia, the paper presents the results of research on motivational factors for dedication at work in company Borbeni složeni sistemi d.o.o. (Complex combat systems Ltd) in Velika Plana. The research was conducted through a questionnaire involving 105 respondents. The results show that higher salary is a motivational factor for the greatest percentage of the respondents. It is followed by greater respect for the employees' rights, job security, rewards for good work performance, greater respect for regulations related to health and safety at work, better interpersonal relationships, better work organisation, better physical working conditions, and finally promotion opportunities.
\end{abstract}

Key words: motivation, motivation for work, motivational factors.

\section{INDRODUCTION}

The 1980s were marked by a strong criticism of social relationships in all socialist countries. The main reasons for criticism and asking for change were the inefficiency of public property, lower standard of living (compared to capitalist societies), failure to exercise personal freedoms and the existence of one-party state. As a result, changes in socio-economic system took place and public property was replaced by private property. With certain variations, capitalism became the dominant socioeconomic system in which work was turned into a commodity whose price was formed on the capital market. By selling his work, man was no longer a social being only but a market being as well: "A

Received October 24, 2017 / Accepted January 16, 2018

Corresponding author: Vesna Miltojević

Faculty of Occupational Safety, Čarnojevića 10a, 18000 Niš, Serbia

E-mail: vesna.miltojevic@ znrfak.ni.ac.rs 
man's activity is productive, useful to society, only when it is sold activity. And the man himself is a productive member of society only if the activities of his daily life are sold activities."[1].

At the time when the social system of Serbia was undergoing changes, Law on privatisation was adopted in 1991, defining the transition from public to private property through workers as shareholders. By 1994 around 50\% of public capital had been turned into private capital, mostly by managers who accumulated private capital through the abuse of public capital [2]. The 1990s were characterised by slow transition, a dramatic drop in the standard of living and the bombing of Serbia as a reaction of the international community to unsuccessful negotiations over Kosovo. Following political changes in 2000, a new neoliberal model of privatisation was introduced, but still with modest results.

Namely, the transitional period is characterised by a low economic growth rate, reduced export, a low employment rate and a drop in the standard of living, which is reflected in the data published by the Statistical Office of the Republic of Serbia. In fact, the process of privatisation of public and state property has brought about a high unemployment rate and insecurity related to exercising the right to work and work-related rights. Trade union representatives point to poor working conditions, questioning the right to form a trade union, lack of solidarity between employees and employers ${ }^{1}$, and finally violating the Labour Law by certain corporations. Transition from public to private property and changes related to social relationships provide ample opportunities for research into basic motivational factors for dedication at work. In that sense, a question arises: what motivates employees to be more dedicated at work?

Research on motivation for work is very significant as motivated employees achieve the aims of an organisation more quickly and easily. Understanding what motivates employees to be more dedicated at work enables management to take measures to increase employees' motivation and productivity, which is the goal of every organisation. In addition, the measures taken create the feeling of satisfaction among employees, and „employees' satisfaction is the only way which can steadily provide high level of productivity and employees' creativity for long-term periods" [3, p. 88].

\section{MOTIVATION AND MOTIVATION FOR WORK}

Maslow defines motivation as a stimulation for fulfilling a person's needs [4, p. 88]. He hierarchically arranges needs into five groups, based on the order of their occurrence and satisfaction: physiological needs (food, water, sleep, sex); safety needs (freedom from fear, social stability, peace); belongingness and love needs (family, friends, children, belonging to social groups); esteem needs (feeling of freedom and independence, social reputation, status and recognition, feeling of achievement) and the need for self-actualisation (fulfilling one's potentials and capacities). When one need has been fulfilled, the next unfulfilled need becomes a motivator.

Unlike the general term motivation, motivation for work refers to "inner driving forces which stimulate the employee to carry out his/ her tasks conscientiously and responsibly, develop professionally, build good working relationships with other employees, build a sense of team work, develop awareness of and responsibility for achieving common goals and

\footnotetext{
${ }^{1}$ http://sindikalizam.org/2017/05/24/nikad-gori-polozaj-radnika-u-srbiji/
} 
interests of a company" [5, p. 312]. The final results of motivation for work should be productivity and satisfaction with work (profitability and humanisation of work), i.e. satisfying personal needs, the needs of an organisation and society as a whole. In that sense, it can be claimed that motivation for work depends not only on individual personal traits and characteristics of an organisation, but also on the degree of development of a society, its system of values, culture, tradition, etc.

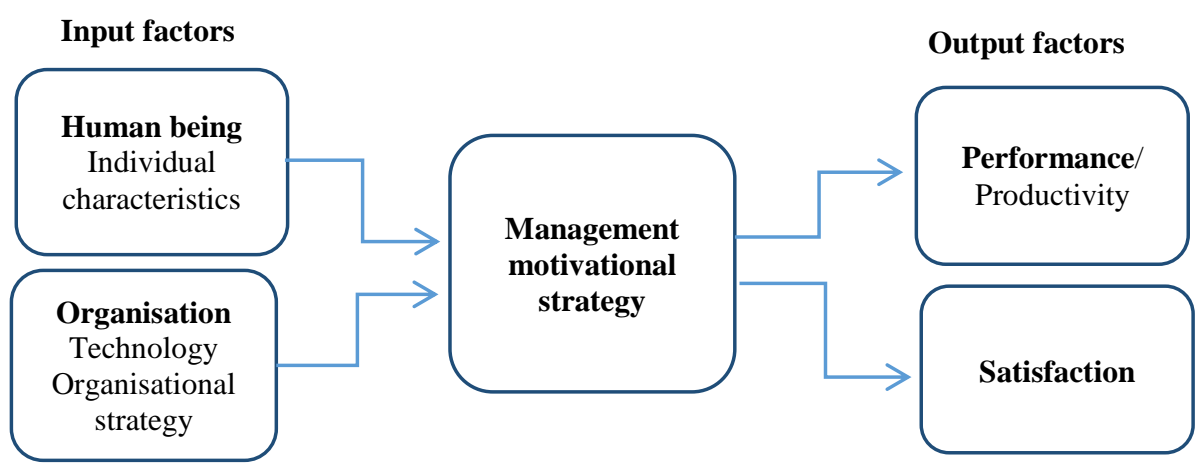

Picture 1 Relationship between motivation and performance ${ }^{[6]}$

However, in altered socioeconomic circumstances, it seems that motivation for work and humanisation of work are profit-oriented; an increase in efficiency, effectiveness and creativity [4] brings more profit through production-related improvements, while motivation for work itself is a function of human resource management process (other functions are stuffing, development and employee retention). [6]

Interest in and research on motivation for work started in the USA at the beginning of the $20^{\text {th }}$ century. In contemporary considerations, theories of motivation for work are usually divided into two major groups, content and process theories of motivation for work, which differ with regard to the sources of motivation for work.

Content theories seek to answer the question what motivates people to behave in a certain way. Maslow's, Adler's, Herzberg's, McClelland's and Atkinson's theories of motivation belong to content theories. Except for Herzberg's theory, other theories do not take into account the influence of the characteristics of work and the working environment as motivational factors and only acknowledge the importance of individual needs for one's relation to work. They are intended to explain why people show interest in certain motivational factors, such as higher salary, promotion, job security etc. while disregarding the importance of some other factors $[7,8,9,10]$.

Process theories (or expectancy theories) set out to answer how people decide to behave in a certain way in the process of work and what processes they apply to determine what is acceptable to them at that moment. They start with the assumption of a willing and conscious choice of alternate behaviour, where individuals are driven by certain expectations of the results and effects of behaviour. Vroom's, Adams', Thorndike's and Drucker's theories belong to process theories of motivation for work $[7,8,9,10]$.

The elements of the above mentioned theories helped to define practical measures for increasing motivation for work in McGregor's Theory X and Theory Y. Theory X emphasises the role of management in directing employees' behaviour and motivating 
employees through persuasion, rewards, punishment and supervision. According to Theory Y, the role of management is to create conditions in which the employees would achieve the goals of the organisation by achieving their goals. Županov believes that the "human relations" model, suggesting that managers should create working conditions in which the employees feel useful and important, and the "human resources" model, according to which working environment makes it possible for the employees to have initiative and develop creativity, can be included in McGregor's Theory Y [8].

Motivation for work represents employees' "orientation toward and incentive to perform a certain action" [8, p. 206] aimed at achieving the goals of the employees and the organisation, and can be influenced by a variety of factors. According to Heathfield, "employee motivation is the combination of fulfilling the employee's needs and expectations from work and the workplace factors that enable employee motivation - or not" [11].

Factors influencing motivation for work can be classified according to several different criteria. They are typically divided into two groups. The first group of factors is related to the employee's job. In that sense, Herzberg proposes job content factors (challenging work, achievement and success, responsibility, opportunity for self-actualisation, advancement and recognition) and job context factors (interpersonal relationships, salary, management and managers, work conditions, job security and company policies). The second group of factors is related to employees' personal traits [see: 9, p. 33-34]. Motivational factors can also be divided into economic factors (salary, rewards etc.) and non-economic factors (work conditions) [12, p. 506].

According to Jušić, motivational factors can be divided into four groups [13]: salary (higher salary and fairer distribution), interpersonal relationships (better relationship with the manager and good colleagues), working conditions (better organisation and better conditions) and self-realisation (promotion opportunities, greater acceptance of suggestions, work that is more socially prestigious and well-informedness).

Besides salary, job security, interpersonal relationships, personal needs, content of work and participation in decision making as motivational factors for dedication at work, Miljković and Živković introduce safety at work as a motivational factor [9, 14].

\section{LITERATURE REVIEW}

The limited research on motivation for work carried out in the countries of the former Socialist Federal Republic of Yugoslavia so far has been conducted using different methods, on different samples and in different periods, which limits the possibility of comparing and making conclusions about the changes regarding the importance of certain motivational factors. Based on the results of the research carried out in 1971, Jušić made a list of factors in order of importance: higher salary, fairer distribution, better relationship with the manager, good colleagues, better organisation, better conditions, promotion opportunities, greater acceptance of suggestions, work that is more socially prestigious and well-informedness [13]. Bojanović and Hrnjica conducted research on the relation between interpersonal relationships and motivation for work, and made the following list of factors: 1. the decisions of selfgoverning bodies, production policy and the immediate supervisor; 2. salary and similar factors; 3. emotional attachment and interpersonal relationships in an organisation; 4. recognition of work results [15]. Based on the results of the research she conducted, Guzina concluded that intrinsic motives were not more important than extrinsic ones [16]. Vujić 
examined the motivation of creative staff from the aspect of Maslow's and Herzberg's theories. The results showed that the need for self-actualisation was the most important motivational factor [17]. Mijačika found that the motivational factors emphasised by employees were extrinsic factors: salary, good working conditions, better relationship between the employee and the manager, friendly relationships with colleagues [10]. In her research, Živković proposed seven motivators for work: salary, job security, interpersonal relationships, personal needs, safety at work, the content of work and participation in decision making. The results revealed that the most important motivational factor was salary. It was followed by job security, safety at work, interpersonal relationships, personal needs, the content of work and finally participation in decision making [9].

\section{RESEARCH TOPICS, AIM AND HYPOTHESIS}

Literature review suggests that there has been little research on motivation for work in the transitional period so far. Having in mind that only motivated employees contribute to achieving the goals of an organisation and that working conditions vary depending on the working environment, the following topic of the research was selected - examining motivation for work in the specific working conditions in company Complex combat systems Ltd.

The production facility of company Complex combat systems Ltd, which is situated in Velika Plana, produces complex combat systems, as well as hunting, sporting and shotgun ammunition. It was opened on December $29^{\text {th }} 2012$ in the former facility of company Goša. The founder of Complex combat systems Ltd was Jugoimport-SDPR, a state-owned firm with a several-decade-long tradition in trade of armaments, military equipment and technology transfer. ${ }^{2}$ The company has seven production facilities and 130 employees. $^{3}$

Investments in the former facility of joint-stock company Goša montaža have brought about improvements in the physical conditions of working environment and modernisation of working equipment, which are among the key motivational factors, besides social and safety climate. The main aim of the paper is to determine the key motivational factors for dedication at work, that is, to determine the relationship between certain demographic characteristics (gender, age, years of work experience, qualifications) ${ }^{4}$ and motivational factors for dedication at work. At the same time, the results of previous studies were taken into account, indicating the relationship between dissatisfaction with certain aspects of work and improvements in these aspects as motivational factors. The results of these studies show that the greater dissatisfaction with certain aspects of work is, the more important improvements in these aspects become as a motivational factor [9, 14].

The starting hypothesis of the research was: The age, years of work experience and qualifications of the respondents do not influence their attitudes regarding higher salary, promotion opportunities, good work performance, job security, better work organisation, better physical working conditions, better social climate, greater respect for the employees' rights and respect for regulations related to health and safety at work as motivational factors for dedication at work.

\footnotetext{
${ }^{2}$ https://www.borbenislozenisistemi.rs/about/

${ }^{3}$ Risk assessment document for Complex combat systems Ltd, 2013.

${ }^{4}$ The relationship between these demographic characteristics and motivational factors for dedication at work has been examined as part of previous research.
} 


\section{RESEARCH MATERIAL AND METHOD}

The data regarding motivation for work were collected through a questionnaire. Out of the 130 employees in the organisation, 105 employees working in various sectors participated in the research. The questionnaire was anonymous and it was conducted from October $18^{\text {th }} 2016$ to October $21^{\text {st }} 2016$. It was composed of closed-ended questions divided into several batteries: demographic characteristics of the respondents, satisfaction with the working environment and motivation for dedication at work. The views on motivation for dedication at work were elicited through a three-point scale, indicating the level to which promotion opportunities, higher salary, rewards for good work, job security, better work organisation, better physical working conditions, social climate, greater respect for the employees' rights and greater respect for regulations related to health and safety at work motivate the respondents to be more dedicated at work (1 - It motivates me, 2 - I am undecided, 3 - It does not motivate me).

Descriptive and non-parametric statistics was used for data interpretation using SPSS (Statistical Package for the Social Sciences) software. The level of significance $p \leq 0.05$ was used for the Chi-Square test, whereas the level $\mathrm{p}<0.05$ was used to determine significance of differences in opinions.

Out of the 105 employees who completed the questionnaire, 92 were men $(87.6 \%)$ and 13 women $(12.4 \%)$, which reflects the ratio of male and female employees. Most questionnaire respondents belonged to the 30-50 age group (56.2\%), then the over-50 $(23.8 \%)$ and finally the under-30 age group (20\%). Most respondents, 55 (52.4\%), had 10 to 30 years of work experience; they were followed by respondents with 5 to 10 years of work experience (24 respondents, or $22.9 \%$ ), less than 5 years (18 respondents, or $17.1 \%$ ) and more than 30 years of work experience (8 respondents, or $7.6 \%$ ). The greatest number of the respondents graduated from secondary school $(67.6 \%)$, then university $(23.8 \%)$, college $(6.7 \%)$ and primary school $(1.9 \%)$.

\section{RESULTS AND DISCUSSION}

\subsection{Salary as a motivational factor}

The greatest percentage of the respondents (more than 90\%) answered that salary would motivate them to be more dedicated at work. This motivational factor was followed by greater respect for the employees' rights, job security, rewards for good work performance, greater respect for regulations related to health and safety at work, better interpersonal relationships, better work organisation, better physical working conditions and promotion opportunities (Chart 1).

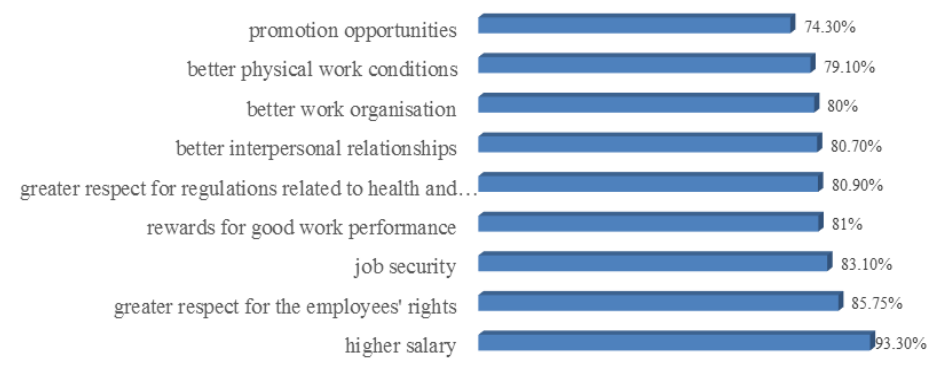

Chart 1 Motivational factors for dedication at work in \% (It motivates me) 
However, there were certain differences related to some demographic characteristics of the respondents. 11 respondents $(52.4 \%)$ belonging to the youngest age category $\left(\mathrm{N}_{\text {(under }}\right.$ $\left.{ }_{30}=23\right)$ answered that they were fairly satisfied with the salary; $8(38.1 \%)$ were not satisfied and $2(9.5 \%)$ were. On the other hand, the greatest number of the respondents belonging to the other two age categories $\left(\mathrm{N}_{(30-50)}=59 ; \mathrm{No}_{(\text {over } 50)}=23\right), 29$ and $13(49.5 \%$ and $56.5 \%)$, were not satisfied with the salary. They were followed by those who were fairly satisfied (27 respondents (45.8\%) belonging to the 30-to-50 age group and 6 respondents $(26.1 \%)$ belonging to the over-50 age group) and satisfied with the salary (3 respondents $(5.1 \%)$ belonging to the 30-to-50 age group and 4 respondents (17.4\%) belonging to the oldest age group. Regardless of the differences, no statistical significance was found, so it cannot be claimed that satisfaction with the salary is influenced by age (Table 1). This is supported by the results of the one-way analysis of variance (ANOVA), at $p<0.05$, examining differences in the respondents' attitudes regarding satisfaction with the salary depending on their age: $F_{(2,103)}=2.424$ and Sig. 0.094. However, dissatisfaction with the salary tended to increase with age, which can be explained by a concern of the respondents who are over 50 about the amount of their pension. The fact that most of the youngest respondents were fairly satisfied with the salary could be explained by the fact that the majority of them $(61.9 \%)$ were not married when the research was conducted, so their salary could satisfy their needs.

Table 1 Age and satisfaction with the salary

\begin{tabular}{lrrrrrrrr}
\hline \multirow{2}{*}{ Age } & \multicolumn{7}{c}{ Are you satisfied with your salary? } \\
\cline { 2 - 9 } & \multicolumn{2}{c}{ Yes } & \multicolumn{1}{c}{ No } & \multicolumn{2}{c}{ Fairly } & \multicolumn{2}{c}{ Total } \\
\cline { 2 - 9 } & $\mathrm{N}$ & \multicolumn{1}{c}{$\mathrm{N}$} & $\%$ & $\mathrm{~N}$ & $\%$ & $\mathrm{~N}$ & $\%$ \\
\hline Under 30 & 2 & $9.5 \%$ & 8 & $38.1 \%$ & 11 & $52.4 \%$ & 21 & $100.0 \%$ \\
30 to 50 & 3 & $5.1 \%$ & 29 & $49.2 \%$ & 27 & $45.8 \%$ & 59 & $100.0 \%$ \\
Over 50 & 4 & $17.4 \%$ & 13 & $56.5 \%$ & 6 & $26.1 \%$ & 23 & $100.0 \%$ \\
\hline Total & 9 & $8.7 \%$ & 50 & $48.6 \%$ & 44 & $42.7 \%$ & 103 & $100.0 \%$ \\
\hline
\end{tabular}

$\chi^{2}=5.742 \mathrm{df}=4$ Asymp. Sig. 0.219

Having in mind the above mentioned results, it is not surprising that the greatest percentage of the respondents answered that higher salary would fully motivate them to be more dedicated at work. The obtained values of statistical significance (Asymp. Sig. 0.497 ) and the data obtained in the one-way analysis of variance examining differences in the respondents' attitudes regarding an increase in salary depending on their age, $F_{(2,102)}=1.072$ and Sig. 0.346, do not reveal statistical significance and statistically significant differences in the respondents' attitudes. Namely, regardless of their age, the greatest number of the respondents, $98(93.3 \%)$, said that an increase in salary would motivate them to be more dedicated at work (under 30: 20 out of 21 respondents $(95.2 \%)$; 30 to 50: 56 out of 59 respondents $(94.9 \%)$ and over 50: 22 out of 25 respondents $(88 \%)$ ). Only $3.8 \%$ of the respondents were undecided (under $30: 1$ out of $21,4.8 \% ; 30$ to $50: 2$ out of $59,3.4 \%$ and over 50: 1 of $25,4 \%$ ), while $2.9 \%$ of the respondents answered that salary would not motivate them to be more dedicated at work (under 30: $0 ; 30$ to $50: 1$ out of $59,1.7 \%$ and over 50: 2 out of $25,8 \%$ ). Although the differences between the groups are not statistically significant, the importance of salary as a motivational factor tended to decrease with age.

Similar results were obtained when the relationship between work experience and satisfaction with the salary was examined. 9 respondents $(50 \%)$ with less than five years of work experience $(\mathrm{N}=18)$ said they were satisfied with their salary, 8 respondents 
$(44.4 \%)$ were not satisfied and $1(5.6 \%)$ was undecided. At the same time, 14 respondents $(58.3 \%)$ with 5 to 10 years of work experience $(\mathrm{N}=24)$ were fairly satisfied with the salary, 8 respondents $(33.3 \%)$ were not satisfied, and $2(8.3 \%)$ were. It can be noticed that dissatisfaction with the salary tended to increase with work experience. More than $50 \%$ of the respondents with more than 10 years of work experience $\left(\mathrm{N}_{(10 \text { to } 30)}=54 ; \mathrm{N}_{(\text {under 30) }}=7\right.$ ) were not satisfied with the salary (30 respondents $(55.6 \%)$ with 10 to 30 years of work experience and 4 respondents $(57.1 \%)$ with more than 30 years of work experience). 20 respondents $(37 \%)$ with 10 to 30 years of work experience were fairly satisfied and 4 $(7.4 \%)$ were satisfied with the salary. Finally, 1 respondent $(14.3 \%)$ with more than 30 years of work experience was fairly satisfied and 2 respondents $(28.6 \%)$ satisfied with the salary. However, the obtained values of statistical significance do not reveal a relationship between years of work experience and satisfaction with the salary (Asymp. Sig. 0.194), and the data obtained in the one-way analysis of variance, $F_{(3,99)}=2.179$ and Sig. 0.095, reveal no differences in the respondents' attitudes regarding satisfaction with the salary depending on their work experience.

However, higher salary would motivate the greatest number of the respondents $(\mathrm{N}=105)$ to be more dedicated at work regardless of their work experience $98(93.3 \%) ; 7(6.7 \%)$ of the respondents were undecided or would not be motivated by higher salary (Table 2$)$.

Table 2 Work experience and higher salary as a motivational factor

\begin{tabular}{|c|c|c|c|c|c|c|c|c|}
\hline \multirow{3}{*}{$\begin{array}{l}\text { Years of work } \\
\text { experience }\end{array}$} & \multicolumn{8}{|c|}{$\begin{array}{c}\text { Which of the following influence your motivation to be more dedicated at } \\
\text { work: higher salary }\end{array}$} \\
\hline & \multicolumn{2}{|c|}{ It motivates me } & \multicolumn{2}{|c|}{ I am undecided } & \multicolumn{2}{|c|}{$\begin{array}{l}\text { It does not } \\
\text { motivate me }\end{array}$} & \multicolumn{2}{|c|}{ Total } \\
\hline & $\mathrm{N}$ & $\%$ & $\mathrm{~N}$ & $\%$ & $\mathrm{~N}$ & $\%$ & $\mathrm{~N}$ & $\%$ \\
\hline Less than 5 years & 18 & $100.0 \%$ & 0 & $0.0 \%$ & 0 & $0.0 \%$ & 18 & $100.0 \%$ \\
\hline 5 to 10 years & 22 & $91.7 \%$ & 1 & $4.2 \%$ & 1 & $4.2 \%$ & 24 & $100.0 \%$ \\
\hline 10 to 30 years & 52 & $94.5 \%$ & 2 & $3.6 \%$ & 1 & $1.8 \%$ & 55 & $100.0 \%$ \\
\hline More than 30 years & 6 & $75.0 \%$ & 1 & $12.5 \%$ & 1 & $12.5 \%$ & 8 & $100.0 \%$ \\
\hline Total & 98 & $93.3 \%$ & 4 & $3.8 \%$ & 3 & $2.9 \%$ & 105 & $100.0 \%$ \\
\hline
\end{tabular}

The obtained value of statistical significance does not reveal a relationship between years of work experience and an increase in salary as a motivational factor for dedication at work, and the values $\mathrm{F}_{(3,101)}=2.045$ and Sig. 0.112 reveal no differences between the groups.

No statistically significant relationship between qualifications and satisfaction with the salary (Asymp. Sig. 0.250) or differences in attitudes between the groups were found $\left(F_{(3,99)}=1.905\right.$ and Sig. 0.134). Also, no differences were found in the respondents' attitudes regarding salary as a motivational factor depending on qualifications (Asymp. Sig. 0.437; $F_{(3,101)}=0.507$ and Sig. 0.678).

\subsection{Promotion opportunities as a motivational factor}

Promotion opportunities would motivate 78 respondents $(74.3 \%)$, would not motivate 20 respondents (19\%), while 7 respodents (6.7\%) were undecided (Table 3). As expected, promotion opportunities as a motivational factor were the most dominant among the youngest respondents and their importance as a motivational factor tended to decrease with age. A 
statistically significant relationship was found between age and promotion opportunities as a motivational factor.

Table 3 Age and promotion opportunities as a motivational factor

\begin{tabular}{|c|c|c|c|c|c|c|c|c|}
\hline \multirow{3}{*}{ Age } & \multicolumn{8}{|c|}{$\begin{array}{l}\text { Which of the following increase your motivation to be more dedicated at work: } \\
\text { promotion opportunities }\end{array}$} \\
\hline & \multicolumn{2}{|c|}{ They motivate me } & \multicolumn{2}{|c|}{ I am undecided } & \multicolumn{2}{|c|}{$\begin{array}{l}\text { They do not } \\
\text { motivate me }\end{array}$} & \multicolumn{2}{|c|}{ Total } \\
\hline & $\mathrm{N}$ & $\%$ & $\mathrm{~N}$ & $\%$ & $\mathrm{~N}$ & $\%$ & $\mathrm{~N}$ & $\%$ \\
\hline Under 30 & 18 & $85.7 \%$ & 0 & $0.0 \%$ & 3 & $14.3 \%$ & 21 & $100.0 \%$ \\
\hline 30 to 50 & 48 & $81.4 \%$ & 4 & $6.8 \%$ & 7 & $11.9 \%$ & 59 & $100.0 \%$ \\
\hline Over 50 & 12 & $48.0 \%$ & 3 & $12.0 \%$ & 10 & $40.0 \%$ & 25 & $100.0 \%$ \\
\hline Total & 78 & $74.3 \%$ & 7 & $6.7 \%$ & 20 & $19.0 \%$ & 105 & $100.0 \%$ \\
\hline
\end{tabular}

The greatest deviation from the obtained mean value in the whole sample $(\mathrm{M}=1.70)$ was noticed among the oldest respondents $(M=2.44)$ and it decreased with a decrease in age (30 to 50: $M=1.49$ and under 30: $M=1.43$ ). The obtained values of the one-way analysis of variance, $F_{(2,102)}=6.576$ and Sig. 0.002, point to differences in attitudes regarding promotion opportunities as a motivational factor between different groups of respondents depending on their age. The difference expressed through the eta square $\left(\eta^{2}\right)$ was 0.114 . Significant differences in attitudes between the groups were found between the oldest respondents and the other two age groups (Table 4).

Table 4 Differences in the respondents' attitudes regarding promotion opportunities depending on their age

\begin{tabular}{lccccc}
\hline Age & Mean & Age & $\begin{array}{c}\text { Mean } \\
\text { Difference }\end{array}$ & Std. Error & Sig. \\
\hline Under 30 & 1.43 & 30 to 50 & -.063 & .296 & .832 \\
& & Over 50 & $-1.011^{*}$ & .344 & .004 \\
\hline 30 to 50 & 1.49 & Under 30 & .063 & .296 & .832 \\
& & Over 50 & $-.948^{*}$ & .278 & .001 \\
\hline Over 50 & 2.44 & 30 to 50 & $1.011^{*}$ & .344 & .004 \\
& & Under 30 & $.948^{*}$ & .278 & .001 \\
\hline
\end{tabular}

Promotion opportunities represented an important motivational factor for the group of the respondents with 5 to 10 years of work experience as they would motivate $22(91.7 \%)$ of them $(\mathrm{N}=24)$; 1 respondent $(4.2 \%)$ was undecided and $1(4.2 \%)$ would not be motivated by promotion opportunities. As for the respondents with less than 5 years of work experience $(\mathrm{N}=18), 15(83.3 \%)$ of them would be motivated by promotion opportunities and $3(16.7 \%)$ would not; there were no respondents in this group who were undecided. 37 respondents $(63.3 \%)$ with 10 to 30 years of work experience $(\mathrm{N}=55)$ would be motivated by this motivational factor, $14(25.5 \%)$ would not, and 4 (7.3\%) were undecided. Finally, 4 respondents $(50 \%)$ with more than 30 years of work experience $(\mathrm{N}=8)$ would be motivated by promotion opportunities, $2(25 \%)$ would not, while $2(25 \%)$ were undecided (Table 5). The importance of promotion opportunities as a motivational factor tended to decrease with work experience - it was the most significant among the respondents with less than 5 years 
of work experience and the least significant among the respondents with most experience.

Table 5 Work experience and promotion opportunities as a motivational factor

\begin{tabular}{|c|c|c|c|c|c|c|c|c|}
\hline \multirow{3}{*}{$\begin{array}{l}\text { Years of work } \\
\text { experience }\end{array}$} & \multicolumn{8}{|c|}{$\begin{array}{l}\text { Which of the following increase your motivation to be more dedicated at work: } \\
\text { promotion opportunities }\end{array}$} \\
\hline & \multicolumn{2}{|c|}{ They motivate me } & \multicolumn{2}{|c|}{ I am undecided } & \multicolumn{2}{|c|}{$\begin{array}{l}\text { They do not } \\
\text { motivate me }\end{array}$} & \multicolumn{2}{|c|}{ Total } \\
\hline & $\mathrm{N}$ & $\%$ & $\mathrm{~N}$ & $\%$ & $\mathrm{~N}$ & $\%$ & $\mathrm{~N}$ & $\%$ \\
\hline Less than 5 & 15 & $83.3 \%$ & 0 & $0.0 \%$ & 3 & $16.7 \%$ & 18 & $100.0 \%$ \\
\hline 5 to 10 & 22 & $91.7 \%$ & 1 & $4.2 \%$ & 1 & $4.2 \%$ & 24 & $100.0 \%$ \\
\hline 10 to 30 & 37 & $67.3 \%$ & 4 & $7.3 \%$ & 14 & $25.5 \%$ & 55 & $100.0 \%$ \\
\hline More than 30 & 4 & $50.0 \%$ & 2 & $25.0 \%$ & 2 & $25.0 \%$ & 8 & $100.0 \%$ \\
\hline Total & 78 & $74.3 \%$ & 7 & $6.7 \%$ & 20 & $19.0 \%$ & 105 & $100.0 \%$ \\
\hline
\end{tabular}

$\chi^{2}=11.840 \mathrm{df}=6$ Asymp. Sig.0.066

The greatest deviation from the obtained value in the whole sample $(\mathrm{M}=1.70)$ was noticed among the respondents with more than 30 years of work experience $(M=2.25)$; the deviation was much smaller among the respondents belonging to the other two groups (less than 5 years of work experience: $M=1.50,5$ to $10: M=1.21,10$ to $30: M=1.91$ ). The values obtained by ANOVA test, $F_{(3,101)}=2.643$ and Sig. 0.053 , are borderline values and they reveal statistically significant differences in the respondents' attitudes regarding promotion opportunities as a motivational factor depending on years of work experience between the respondents with 5 to 10 and 10 to 30 years of work experience, and the respondents with 5 to 10 and more than 30 years of work experience (Table 6).

Table 6 Differences in the respondents' attitudes regarding promotion opportunities as a motivational factor depending on years of work experience

\begin{tabular}{|c|c|c|c|c|c|}
\hline $\begin{array}{l}\text { Years of work } \\
\text { experience }\end{array}$ & Mean & $\begin{array}{c}\text { Years of work } \\
\text { experience }\end{array}$ & $\begin{array}{c}\text { Mean } \\
\text { Difference }\end{array}$ & Std. Error & Sig. \\
\hline \multirow{3}{*}{ Less than 5} & \multirow{3}{*}{1.50} & 5 to 10 & .292 & .373 & .436 \\
\hline & & 10 to 30 & -.409 & .325 & .211 \\
\hline & & More than 30 & -.750 & .508 & .143 \\
\hline \multirow{3}{*}{5 to 10} & \multirow{3}{*}{1.21} & Less than 5 & -.292 & .373 & .436 \\
\hline & & 10 to 30 & $-.701^{*}$ & .293 & .018 \\
\hline & & More than 30 & $-1.042^{*}$ & .488 & .035 \\
\hline \multirow{3}{*}{10 to 30} & \multirow{3}{*}{1.91} & Less than 5 & .409 & .325 & .211 \\
\hline & & 5 to 10 & $.701^{*}$ & .293 & .018 \\
\hline & & More than 30 & -.341 & .453 & .453 \\
\hline \multirow{3}{*}{ More than 30} & \multirow{3}{*}{2.25} & Less than 5 & .750 & .508 & .143 \\
\hline & & 5 to 10 & $1.042^{*}$ & .488 & .035 \\
\hline & & 10 to 30 & .341 & .453 & .453 \\
\hline
\end{tabular}

A statistically significant relationship between qualifications and promotion opportunities as a motivational factor was not found (Asymp. Sig. 0.664, the values of ANOVA test $\left(F_{(3,101)}=0.971\right.$, Sig. 0.409). 


\subsection{Rewards for good work performance as a motivational factor}

Rewards for good work performance would fully motivate 85 respondents $(81 \%)$, would not motivate $16(15.2 \%)$, while 4 respondents $(3.8 \%)$ were undecided. As far as the respondents belonging to the 30-to-50 age group are concerned, the greatest number of them, $51(86.4 \%)$, stated that rewards would motivate them to be more dedicated at work, while 2 respondents $(3.4 \%)$ were undecided; finally, this motivational factor would not motivate 6 respondents $(10.2 \%)$ belonging to the 30-to-50 age group. Rewards for good work performance were of somewhat lesser importance for the youngest respondents $-18(85.7 \%)$ of them would be motivated by this factor and $3(14.3 \%)$ would not. As for the over-50 respondents, $16(64 \%)$ of them would be motivated by rewards, 7 $(28 \%)$ would not, and 2 (8\%) were undecided (Table 7).

Table 7 Age and rewards for good work performance as a motivational factor

\begin{tabular}{|c|c|c|c|c|c|c|c|c|}
\hline \multirow{3}{*}{ Age } & \multicolumn{8}{|c|}{$\begin{array}{l}\text { Which of the following increase your motivation to be more dedicated at work: } \\
\text { rewards for good work performance }\end{array}$} \\
\hline & \multicolumn{2}{|c|}{ They motivate me } & \multicolumn{2}{|c|}{ I am undecided } & \multicolumn{2}{|c|}{$\begin{array}{l}\text { They do not } \\
\text { motivate me }\end{array}$} & \multicolumn{2}{|c|}{ Total } \\
\hline & $\mathrm{N}$ & $\%$ & $\mathrm{~N}$ & $\%$ & $\mathrm{~N}$ & $\%$ & $\mathrm{~N}$ & $\%$ \\
\hline Under 30 & 18 & $85.7 \%$ & 0 & $0.0 \%$ & 3 & $14.3 \%$ & 21 & $100.0 \%$ \\
\hline 30 to 50 & 51 & $86.4 \%$ & 2 & $3.4 \%$ & 6 & $10.2 \%$ & 59 & $100.0 \%$ \\
\hline Over 50 & 16 & $64.0 \%$ & 2 & $8.0 \%$ & 7 & $28.0 \%$ & 25 & $100.0 \%$ \\
\hline Total & 85 & $81.0 \%$ & 4 & $3.8 \%$ & 16 & $15.2 \%$ & 105 & $100.0 \%$ \\
\hline
\end{tabular}

The value Asymp. Sig. 0.145 reveals that there is no statistically significant relationship between age and rewards as a motivational factor for dedication at work. The distribution of answers expressed in percentages shows that the number of the respondents who were undecided tended to increase with age (the greatest number of the respondents who were undecided were among the oldest respondents, and there were no respondents belonging to the youngest age group that were undecided).

The results reveal a statistically significant relationship between years of work experience and attitudes regarding rewards for good performance as a motivational factor. Rewards would motivate 16 respondents $(88.9 \%)$ with less than 5 years of work experience $(\mathrm{N}=18)$, and would not motivate 2 respondents $(11.1 \%)$; there were no respondents who were undecided. As for the respondents with 5 to 10 years of work experience $(\mathrm{N}=24), 23(95.8 \%)$ of them would be motivated by rewards and 1 (4.2\%) would not. Again, there were no respondents who were undecided. As far as the respondents with 10 to 30 years of work experience are concerned $(\mathrm{N}=56)$, the greatest number of them, $41(74.5 \%)$, would be motivated by rewards (Table 8). However, regardless of certain differences, the values obtained by ANOVA test, $\mathrm{F}_{(3,101)}=2.124$ and Sig. 0.102 , do not reveal statistically significant differences in the respondents' attitudes regarding rewards for good work performance as a motivational factor depending on years of work experience. 
Table 8 Work experience and rewards for good work performance as a motivational factor

\begin{tabular}{|c|c|c|c|c|c|c|c|c|}
\hline \multirow{3}{*}{$\begin{array}{l}\text { Years of work } \\
\text { experience }\end{array}$} & \multicolumn{8}{|c|}{$\begin{array}{c}\text { Which of the following increase your motivation to be more dedicated at work: } \\
\text { rewards for good work performance }\end{array}$} \\
\hline & \multicolumn{2}{|c|}{ They motivate me } & \multicolumn{2}{|c|}{ I am undecided } & \multicolumn{2}{|c|}{$\begin{array}{l}\text { They do not } \\
\text { motivate me }\end{array}$} & \multicolumn{2}{|c|}{ Total } \\
\hline & $\mathrm{N}$ & $\%$ & $\mathrm{~N}$ & $\%$ & $\mathrm{~N}$ & $\%$ & $\mathrm{~N}$ & $\%$ \\
\hline Less than 5 & 16 & $88.9 \%$ & 0 & $0.0 \%$ & 2 & $11.1 \%$ & 18 & $100.0 \%$ \\
\hline 5 to 10 & 23 & $95.8 \%$ & 0 & $0.0 \%$ & 1 & $4.2 \%$ & 24 & $100.0 \%$ \\
\hline 10 to 30 & 41 & $74.5 \%$ & 2 & $3.6 \%$ & 12 & $21.8 \%$ & 56 & $100.0 \%$ \\
\hline More than 30 & 5 & $62.5 \%$ & 2 & $25.0 \%$ & 1 & $12.5 \%$ & 8 & $100.0 \%$ \\
\hline Total & 85 & $81.0 \%$ & 4 & $3.8 \%$ & 16 & $15.2 \%$ & 105 & $100.0 \%$ \\
\hline
\end{tabular}

A statistically significant relationship between qualifications and rewards for good work performance as motivational factor was not found (Asymp. Sig. 0.635) and the obtained values of the one-way analysis of variance do not reveal statistically significant differences between the groups $\left(\mathrm{F}_{(3,101)}=1.386\right.$, Sig. 0.252).

\subsection{Job security as a motivational factor}

Job security is a factor which would motivate 87 respondents $(82.9 \%)$ to be more dedicated at work and would not motivate $13(12.4 \%) ; 5$ respondents (4.8\%) were undecided about the motivational value of this motivational factor. The obtained values of statistical significance do not reveal a statistically significant relationship between age (Asymp. Sig. 0.299), years of work experience (Asymp. Sig. 0.780) and qualifications (Asymp. Sig. 0.766), on one hand, and job security as a motivational factor, on the other. Also, the values obtained by ANOVA test do not show statistically significant differences in attitudes between the groups regarding job security as a motivational factor (age: $F_{(2,102)}=2.039$, Sig. 0.135; work experience: $F_{(3,101)}=0.651$, Sig. 0.584; qualifications: $\mathrm{F}_{(3,101)}=0.483$, Sig. 0.695).

\subsection{Better work organisation as a motivational factor}

84 respondents $(80 \%)$ said that better work organisation would motivate them to be more dedicated at work; this factor would not motivate 14 respondents $(13.3 \%)$, while 7 $(6.7 \%)$ were undecided (Table 9). The greatest percentage of the respondents in each group stated that better work organisation would motivate them to be more dedicated at work. Unlike the youngest age group, in which 5 respondents $(23.8 \%)$ were undecided, a considerably smaller number of the respondents in the other two age groups felt undecided (30 to 50: 1, 1.7\% and over 50: 1, 4\%). At the same time, 7 respondents $(28 \%$ ) belonging to the oldest age group said that better work organisation would not motivate them at all; this is a much higher percentage compared to the other age groups (under 30: 2, 9.5\%; 30 to 50: $5,8.5 \%$ ). The results reveal a statistically significant relationship between age and better work organisation as a motivational factor (Asymp. Sig. 0.001). 
Table 9 Age and better work organisation as a motivational factor

\begin{tabular}{|c|c|c|c|c|c|c|c|c|}
\hline \multirow{3}{*}{ Age } & \multicolumn{8}{|c|}{$\begin{array}{l}\text { Which of the following increase your motivation to be more dedicated at work: } \\
\text { better work organisation }\end{array}$} \\
\hline & \multicolumn{2}{|c|}{ It motivates me } & \multicolumn{2}{|c|}{ I am undecided } & \multicolumn{2}{|c|}{$\begin{array}{l}\text { It does not } \\
\text { motivate me }\end{array}$} & \multicolumn{2}{|c|}{ Total } \\
\hline & $\mathrm{N}$ & $\%$ & $\mathrm{~N}$ & $\%$ & $\mathrm{~N}$ & $\%$ & $\mathrm{~N}$ & $\%$ \\
\hline Under 30 & 14 & $66.7 \%$ & 5 & $23.8 \%$ & 2 & $9.5 \%$ & 21 & $100.0 \%$ \\
\hline 30 to 50 & 53 & $89.8 \%$ & 1 & $1.7 \%$ & 5 & $8.5 \%$ & 59 & $100.0 \%$ \\
\hline Over 50 & 17 & $68.0 \%$ & 1 & $4.0 \%$ & 7 & $28.0 \%$ & 25 & $100.0 \%$ \\
\hline Total & 84 & $80.0 \%$ & 7 & $6.7 \%$ & 14 & $13.3 \%$ & 105 & $100.0 \%$ \\
\hline
\end{tabular}

The greatest deviation from the mean value $M=1.53$ in the whole sample was found among the oldest respondents, $M=1.92$. The values obtained by ANOVA test, $F_{(2,102)}=3.693$ and Sig. 0.028, show statistically significant differences in the respondents' attitudes regarding better work organisation as a motivational factor for dedication at work between the age groups. The difference expressed through the eta square $\left(\eta^{2}\right)$ was 0.068 . A statistically significant difference was found between the 30-to-50 and the over-50 respondents (Table 10).

Table 10 Differences in the respondents' attitudes regarding better work organisation depending on age

\begin{tabular}{lccccc}
\hline Age & Mean & Age & $\begin{array}{c}\text { Mean } \\
\text { Difference }\end{array}$ & Std. Error & Sig. \\
\hline Under 30 & 1.76 & 30 to 50 & .474 & .271 & .083 \\
& & Over 50 & -.158 & .315 & .617 \\
\hline 30 to 50 & 1.29 & Under 30 & -.474 & .271 & .083 \\
& & Over 50 & $-.632^{*}$ & .254 & .015 \\
\hline Over 50 & 1.92 & 30 to 50 & .158 & .315 & .617 \\
& & Under 30 & $.632^{*}$ & .254 & .015 \\
\hline
\end{tabular}

Statistically significant relationships between years of work experience and qualifications, on the one hand, and better work organisation, on the other, were not found (Asymp. Sig. 0.433 and Asymp. Sig. 0.098); also, statistically significant differences in attitudes between the groups were not found $\left(\mathrm{F}_{(3,102)}=0.546\right.$ and Sig. 0.652 , and $\mathrm{F}_{(3,101)}=0.413$ and Sig. 0.744).

\subsection{Better physical working conditions as a motivational factor}

24 respondents $(24.8 \%)$ perceived physical working conditions (damp, dust, noise, coldness etc.) as very good, $52(49.5 \%)$ as satisfactory, $19(18.1 \%)$ as bad and $8(7.6 \%)$ as very bad. Therefore, it is not surprising that the greatest number of the respondents, 83 (79\%), said that better physical working conditions would motivate them; this factor would not motivate 14 respondents $(13.3 \%)$, while 8 respondents $(7.6 \%)$ were undecided (Table $11)$. The greatest number of the youngest respondents, $17(81 \%)$, would be motivated by better physical working conditions, $3(14.8 \%)$ were undecided, and $1(4.8 \%)$ would not be motivated by this motivational factor $(\mathrm{N}=21)$. As for the 30 -to-50 respondents $(\mathrm{N}=59), 50$ respondents $(84.1 \%)$ would be motivated by better physical working conditions, $5(8.5 \%)$ 
would not, while $4(6.8 \%)$ were undecided. As for the oldest group $(\mathrm{N}=25)$, better physical working conditions would motivate 16 respondents $(64 \%)$ and would not motivate as many as $8(32 \%)$; only 1 respondent $(4 \%)$ belonging to the over-50 group was undecided (Table 11). The number of the respondents who felt undecided about the importance of this motivational factor tended to decrease with age, while the number of those who would not be motivated by better physical conditions at work tended to increase with age.

Table 11 Age and better physical working conditions as a motivational factor

\begin{tabular}{|c|c|c|c|c|c|c|c|c|}
\hline \multirow{3}{*}{ Age } & \multicolumn{8}{|c|}{$\begin{array}{l}\text { Which of the following increase your motivation to be more dedicated at work: } \\
\text { better physical working conditions }\end{array}$} \\
\hline & \multicolumn{2}{|c|}{ They motivate me } & \multicolumn{2}{|c|}{ I am undecided } & \multicolumn{2}{|c|}{$\begin{array}{l}\text { They do not } \\
\text { motivate me }\end{array}$} & \multicolumn{2}{|c|}{ Total } \\
\hline & $\mathrm{N}$ & $\%$ & $\mathrm{~N}$ & $\%$ & $\mathrm{~N}$ & $\%$ & $\mathrm{~N}$ & $\%$ \\
\hline Under 30 & 17 & $81.0 \%$ & 3 & $14.3 \%$ & 1 & $4.8 \%$ & 21 & $100.0 \%$ \\
\hline 30 to 50 & 50 & $84.7 \%$ & 4 & $6.8 \%$ & 5 & $8.5 \%$ & 59 & $100.0 \%$ \\
\hline Over 50 & 16 & $64.0 \%$ & 1 & $4.0 \%$ & 8 & $32.0 \%$ & 25 & $100.0 \%$ \\
\hline Total & 83 & $79.0 \%$ & 8 & $7.6 \%$ & 14 & $13.3 \%$ & 105 & $100.0 \%$ \\
\hline
\end{tabular}

The values obtained by ANOVA test, $\mathrm{F}_{(2,102)}=3.378$ and Sig. 0.038 , point to statistically significant differences in the respondents' attitudes regarding physical conditions at work as a motivational factor for dedication at work between the 30-to-50 and the over-50 respondents (Table 12). The difference expressed through the eta square $\left(\eta^{2}\right)$ was 0.062 . In addition, the greatest deviation from the mean value in the whole sample $(M=1.53)$ was noticed among the oldest respondents.

Table 12 Differences in the respondents' attitudes regarding better physical working conditions depending on age

\begin{tabular}{lccccc}
\hline Age & Mean & Godine života & $\begin{array}{c}\text { Mean } \\
\text { Difference }\end{array}$ & Std. Error & Sig. \\
\hline Under 30 & & & .039 & .273 & .888 \\
& 1.43 & 30 to 50 & -.611 & .319 & .058 \\
\hline 30 to 50 & & Over 50 & -.039 & .273 & .888 \\
& \multirow{2}{*}{1.39} & Under 30 & $-.650^{*}$ & .257 & .013 \\
\hline Over 50 & & Over 50 & .611 & .319 & .058 \\
& 2.04 & Under 30 & $.650^{*}$ & .257 & .013 \\
\hline
\end{tabular}

Statistically significant relationships between years of work experience and qualifications, on the one hand, and better physical working conditions, on the other, were not found (Asymp. Sig. 0.406 and Asymp. Sig. 0.860); statistically significant differences in attitudes between the groups were not found either $\left(F_{(3,101)}=1.187\right.$ and Sig. $0.319, F_{(3,101)}=0.283$ and Sig. 0.381).

\subsection{Better interpersonal relationships as a motivational factor}

The greatest number of the respondents were satisfied with the social climate in the organisation. $80(78.1 \%)$ of them stated that they felt good among the colleagues while 
$23(21.9 \%)$ felt sometimes good and sometimes bad. In addition, the greatest number of the respondents, 50 of them $(48.1 \%)$, perceived the relationship with their manager as good, while 24 respondents $(23.1 \%)$ viewed this relationship as sometimes good and sometimes bad. 18 respondents believed that their managers sometimes did not treat them fairly (17.3\%), 10 of them felt that the managers did not appreciate them enough $(9.6 \%)$, while 2 respondents $(1.9 \%)$ felt the managers treated them badly. Yet, better interpersonal relationships would motivate $85(81 \%)$ of the respondents to be more dedicated at work, would not motivate 13 (12.4\%), while 7 (6.7\%) were undecided. The obtained values do not reveal statistically significant relationships between age, years of work experience and qualifications, on the one hand, and better interpersonal relationships as a motivational factor, on the other (Asymp. Sig. 0.346, Asymp. Sig. 0.258 and Asymp. Sig. 0.650). Also, the values of the one-way analysis of variance do not indicate statistically significant differences between better interpersonal relationships and the age, years of work experience or qualifications of the respondents $\left(F_{(2,102)}=1.317\right.$ Sig. $0.273, F_{(3,101)}=0.349$ Sig. 0.790 and $F_{(3,101)}=0.925$ Sig. 0.432).

\subsection{Greater respect for the employees' rights as a motivational factor}

Greater respect for the employees' rights would fully motivate $90(85.7 \%)$ and would not motivate 9 respondents $(8.6 \%) ; 6$ respondents $(5.7 \%)$ were undecided. The greatest number of the respondents felt that greater respect for the employees' rights would motivate them to be more dedicated at work (under 30: $18,85.7 \%$ : 30 to 50: 53, 89.8\%, over 50: 19, $76 \%)$. At the same time, 4 respondents $(6.8 \%)$ belonging to the 30 -to-50 age group and 5 respondents $(20.0 \%)$ belonging to the over-50 group would not be motivated by this motivational factor (Table 13). The importance of greater respect for the employees' rights as a motivational factor tended to decrease with age. Statistical significance is close to the established level of significance, but there are no statistically significant differences between the groups $\left(\mathrm{F}_{(2,102)}=1.825 \mathrm{Sig}\right.$. 0.166$)$.

Table 13 Age and greater respect for the employees' rights as a motivational factor

\begin{tabular}{|c|c|c|c|c|c|c|c|c|}
\hline \multirow{3}{*}{ Age } & \multicolumn{8}{|c|}{$\begin{array}{l}\text { Which of the following increase your motivation to be more dedicated at work: } \\
\text { greater respect for the employees' rights }\end{array}$} \\
\hline & \multicolumn{2}{|c|}{ It motivates me } & \multicolumn{2}{|c|}{ I am undecided } & \multicolumn{2}{|c|}{$\begin{array}{l}\text { It does not } \\
\text { motivate me }\end{array}$} & \multicolumn{2}{|c|}{ Total } \\
\hline & $\mathrm{N}$ & $\%$ & $\mathrm{~N}$ & $\%$ & $\mathrm{~N}$ & $\%$ & $\mathrm{~N}$ & $\%$ \\
\hline Under 30 & 18 & $85.7 \%$ & 3 & $14.3 \%$ & 0 & $0.0 \%$ & 21 & $100.0 \%$ \\
\hline 30 to 50 & 53 & $89.8 \%$ & 2 & $3.4 \%$ & 4 & $6.8 \%$ & 59 & $100.0 \%$ \\
\hline Over 50 & 19 & $76.0 \%$ & 1 & $4.0 \%$ & 5 & $20.0 \%$ & 25 & $100.0 \%$ \\
\hline Total & 90 & $85.7 \%$ & 6 & $5.7 \%$ & 9 & $8.6 \%$ & 105 & $100.0 \%$ \\
\hline
\end{tabular}

The obtained results do not point to statistically significant relationships between years of work experience and qualifications, on the one hand, and respect for the employees' rights as a motivational factor for dedication at work, on the other (Asymp. Sig. 0.685 and Asymp. Sig. 0.113), or to statistically significant differences between the groups $F_{(3 \text {, }}$ $101)=0.303$ Sig. 0.823 and $F_{(3,101)}=0.334$ Sig. 0.801). 


\subsection{Respect for regulations related to health and safety at work as a motivational factor}

The greatest percentage of the respondents, $44.8 \%$, thought that the health and safety officer visited them very often, $41 \%$ felt that he/she visited them often, $9.5 \%$ were undecided, and finally $4.8 \%$ believed that he/she rarely visited them. Respect for regulations related to health and safety at work would fully motivate $85(81 \%)$ and would not motivate 12 respondents $(11.4 \%) ; 8$ respondents $(7.6 . \%)$ were undecided. Even though the values obtained by ANOVA test $\left(\mathrm{F}_{(2,102)}=1.212 \mathrm{Sig}\right.$. 0.302$)$ do not point to statistically significant differences in attitudes regarding greater respect for regulations related to health and safety at work as a motivational factor between different age groups, the importance of this motivational factor tended to decrease with age. This can be explained by a greater awareness of the importance of health and safety at work among the youngest respondents. (Table 14).

Table 14 Age and respect for regulations related to health and safety at work as a motivational factor

\begin{tabular}{|c|c|c|c|c|c|c|c|c|}
\hline \multirow{3}{*}{ Age } & \multicolumn{8}{|c|}{$\begin{array}{l}\text { Which of the following increase your motivation to be more dedicated at work: } \\
\text { respect for regulations related to health and safety at work }\end{array}$} \\
\hline & \multicolumn{2}{|c|}{ It motivates me } & \multicolumn{2}{|c|}{ I am undecided } & \multicolumn{2}{|c|}{$\begin{array}{l}\text { It does not motivate } \\
\text { me }\end{array}$} & \multicolumn{2}{|c|}{ Total } \\
\hline & $\mathrm{N}$ & $\%$ & $\mathrm{~N}$ & $\%$ & $\mathrm{~N}$ & $\%$ & $\mathrm{~N}$ & $\%$ \\
\hline Under 30 & 16 & $76.2 \%$ & 4 & $19.0 \%$ & 1 & $4.8 \%$ & 21 & $100.0 \%$ \\
\hline 30 to 50 & 51 & $86.4 \%$ & 2 & $3.4 \%$ & 6 & $10.2 \%$ & 59 & $100.0 \%$ \\
\hline Over 50 & 18 & $72.0 \%$ & 2 & $8.0 \%$ & 5 & $20.0 \%$ & 25 & $100.0 \%$ \\
\hline Total & 85 & $81.0 \%$ & 8 & $7.6 \%$ & 12 & $11.4 \%$ & 105 & $100.0 \%$ \\
\hline
\end{tabular}

The results do not reveal statistically significant relationships between work experience and qualifications, on the one hand, and respect for regulations related to health and safety at work as a motivational factor for dedication at work, on the other (Asymp. Sig. 0.726 and Asymp. Sig. 0.559), or to statistically significant differences between the groups $\left(\mathrm{F}_{(3 \text {, }}\right.$ $101)=0.050$ Sig. 0.985 and $F_{(3,101)}=0.573$ Sig. 0.634).

\section{CONCLUSION}

The results indicate that the respondents perceive all the motivational factors as important, but three factors should be given special attention: salary, greater respect for the employees' rights and promotion opportunities. The fact that higher salary is a significant motivational factor for dedication at work is in line with the data obtained in previous research $[8,9,10,12]$ and indicates that this motivational factor has not lost importance even though socioeconomic circumstances under which the working process takes place have changed. However, although salary, job security and rewards for good work performance are relevant motivational factors, this does not mean that the respondents are interested only in the material aspects. Under the circumstances when trade unions have become less significant and their fight for respecting the employees' rights has almost lost importance, except for extreme cases, greater respect for the employees' rights as well as greater respect for regulations related to health and safety at work are emerging as major 
motivational factors. As expected, higher salary is a significant motivational factor for dedication at work, but it is surprising that the lowest percentage of the respondents stated that promotion opportunities would motivate them to be more dedicated at work. At the time when it is difficult to find employment, it seems that the very fact that one is employed is enough, which negatively influences individual needs for development and achievement.

The results lead to the conclusion that the hypothesis was partly confirmed. Higher salary, rewards for good work performance, job security, social climate and respect for regulations related to health and safety at work are significant motivational factors for dedication at work regardless of age, years of work experience and qualifications. On the other hand, attitudes regarding promotion opportunities and greater respect for the employees' rights as motivational factors are influenced by age and years of work experience. Finally, age was found to influence attitudes regarding better work organisation and better physical work conditions as motivational factors.

Translated by: Aleksandra Savić, MA in Philology

Acknowledgement: This paper was written as part of the project No. 179013, financed by the Ministry of Education, Science and Technological Development of the Republic of Serbia.

The data presented in the paper were collected as part of the Master thesis of the first author.

\section{REFERENCES}

1. Perlman, F. (2003). Reprodukcija svakodnevnog života i drugi eseji" ("The reproduction of daily life and other essays". Anarhija/blok, 45.

2. Musić, G. (2013). Radnička klasa Srbije u tranziciji 1988 - 2013 (The working class in Serbia in the transition process from 1988 to 2013). Beograd: Rosa Luxemburg Stiftung, Regionalna kancelarijia za Jugoistočnu Evropu.

3. Rakić, T., Živković, S., Veljković, M. (2017). Hierarchy of Work Motives and Motivators With the Aim of Forming More Efficient Working Environment. Facta Universitatis Series: Working and Living Environmental Protection, 14(1): 87 - 98. DOI: 10.22190/FUWLEP1701087R

4. Maslov, H. (1982). Motivacija i ličnost (Motivation and personality). Beograd: Nolit.

5. Marinković, D., Marinković, V. (2015). Enciklopedija industrijskih odnosa (Encyclopedia of industrial relationships). Beograd: JP Službeni glasnik.

6. Štangl Šušnjar, G., Zimanji, V. (2006). Menadžment ljudskih resursa (Human resource management). Subotica: Ekonomski fakultet.

7. Bahtijarević-Šiber, F. (1999). Management ljudskih potencijala (Management of human potentials). Zagreb: Golden marketing.

8. Bolčić, S. (2003). Svet rada u transformaciji (The world of work in transformation). Beograd: Plato.

9. Živković, B. S. (2007). Motivacija za zaštitu na radu (Motivation for safety at work). Niš: Fakultet zaštite na radu.

10. Mijačika, N. (1989). Motivacija za rad i istraživanje nekih njenih aspekata (Labour motivation and a survey of some of its aspects). Rev. za soc., XX(1-2): 151-164.

11. Heathfield, M. S. (2017). You Need to Know What Motivation Is-Really Want to Encourage and Inspire Employee Motivation? Available from: https://www.thebalance.com/what-is-employee-motivation1918108. (30.12.2018)

12. Žarevac Bošković, M. (2017). Workforce Motivation As a Factor of Productivity. Teme, XLI(2): 503516. DOI: 10.22190/TEME1702503Z

13. Jušić, B. (1971). Da li radimo zbog novca (Do we work because of money). Psihologija, no. 1-2.

14. Миљковић, J. (1984). Мотивачија за рад и остваривање безбедних услова рада (Motivation for work and creating safe working conditions ), докторска дисертација. Ниш: Факултет заштите на раду. 
15. Bojanović, R., Hrnjica, S. (1972). Radnikova percepcija međuljudskih odnosa u radnoj organizaciji i motivacija za rad (The employee's perception of interpersonal relationships in an organisation and motivation for work), u Psihološke rasprave - IV kongres psihologa, str. 335-342.

16. Guzina, M. (1988). Motivacija za rad i zadovoljstvo poslom radnika (Employees' motivation for work and job satisfaction). Beograd: Institut za psihologiju.

17. Vujić, D. (1995). Motivacija za rad kreativnog kadra u uslovima krize društvene i organizacijske sredine (Motivation for work of creative staff at the time of crisis in social and organisational environment). Psihologija, 3-4: 339-354.

\section{MOTIVACIONI FAKTORI ZALAGANJA NA POSLU - STUDIJA SLUČAJA}

Motivacija za rad u izmenjenim društvenim okolnostima u Republici Srbiji nije često predmet istraživanja, mada na osnovu pregleda literarnih jedinica nije bila u žiži interesovanja ni pre raspada SFRJ, ali ni u vreme tranzicionih procesa u Srbiji. Posle kratkog prikaza različitih pristupa motivaciji, motivaciji za rad i rezultata istraživanja na tlu bivše SFRJ i Republike Srbije, izloženi su rezultati istraživanja motivacionih faktora zalaganja na poslu u privrednom društvu „Borbeni složeni sistemi” d.o.o. iz Velike Plane. Istraživanje je sprovedeno tehnikom anketnog ispitivanja na uzorku od 105 ispitanika. Na osnovu dobijenih rezultata došlo se do saznanja da je veća plata za najveći procenat ispitanika motivacioni faktor. Na osnovu distribucije odgovora izražene u procentima slede: veće poštovanje prava radnika, sigurnost zaposlenja, nagrada za dobro obavljeni posao, veće poštovanje propisa iz oblasti bezbednosti $i$ zdravlja na radu, bolji međuljudski odnosi, bolja organizacija rada, bolji fizički uslovi rada i na kraju mogućnost napredovanja.

Ključne reči: motivacija, motivacija za rad, motivacioni faktori. 